Filología y Linguística XXIV(2): 239-243, 1998

\title{
RACE AND ETHNICITY IN THE FOLKLORE OF BELIZE
}

\author{
Timothy W. Hagerty
}

\begin{abstract}
RESUMEN
Este artículo presenta los resultados de mi estudio sobre raza y etnicidad en el folclor de Belice, en el cual examiné tres volúmenes inéditos de canciones e historias folclóricas criollas recolectadas por Ervin Beck, así como 400 páginas de mi colección inédita de narrativa folclórica criolla e hispana de Belice. En estos materiales encontré pocas referencias a aspectos raciales y étnicos, lo cual permite afirmar que existe un bajo nivel de tensión interracial en Belice.
\end{abstract}

\begin{abstract}
This paper presents the results of my study of race and ethnicity in the folklore of Belize, for which I examined three unpublished volumes of Creole folktales and folksongs collected by Ervin Beck, as well as 400 pages of my own unpublished collection of both Creole and Hispanic folk narrative from Belize. In these materials, I found few references to issues of race and ethnicity, a fact that supports the assertion of low interracial stress in Belize.
\end{abstract}

In Belize, living with the racial and ethnic Other is a fact of life; indeed, it is a way of life. Belizeans are proud of how peaceful this way of life is in their country and assert that they have achieved an almost perfect racial harmony in a very heterogeneous society. This paper presents the results of my study of race and ethnicity in the folklore of Belize, for which I examined three unpublished volumes of Creole folktales and folksongs collected by Ervin Beck, as well as 400 pages of my own unpublished collection of both Creole and Hispanic folk narrative from Belize. In these materials, I found few references to issues of race and ethnicity, a fact that supports the assertion of low interracial stress in Belize. My research did show, however, that Belizeans are quite aware of the ethnic and racial differences among them, and occasionally there is an indication of the presence of a racial hierarchy in the collective Belizean unconscious.

In order to arrive at a clearer understanding of the present status of attitudes toward ethnic and racial matters in Belize, I have divided this study into an examination of, first, folklore that confirms the awareness and importance of race in Belize but that contains no comment on its content; second, folklore that implies the existence of a racial hierarchy in Belize; 
and third, one intriguing folksong that evidences both awareness of the mentioned racial hierarchy and apparent acceptance of that hierarchy.

Among the several examples I found of folklore that attests only to an awareness of ethnic and racial differences, there are two in which the mixing of Spanish and English is in itself an indication of that awareness. The first of these examples is an Anansi tale in which Anansi violates his own proscription against gossipping and is subsequently punished (Hagerty 1978: 382). An aspect of the tale that seems quite important to the tale teller is the nationality of one of Anansi's animal friends, the Guinea hen. The narrator makes a point of explaining that the hen is British and speaks English: "Wait', dice, dice la, la Guinea hen. Dice, 'Así yo-', pero en inglés, porque ella era inglesa. El Guinea hen habla inglés." ("'Wait,' says the Guinea hen. She says, 'Así yo...,' but in English because she is English. The Guinea hen speaks English.") And the hen then continues speaking to Anansi in English (see Parham and Hagerty 1988).

The second instance I encountered of the mixing of Spanish and English is a song that begins, "I went dung to Cayo in January," collected by Ervin Beck (1978: 85). Here we find the same awareness of ethnic differences that is present in the Anansi tale, and the same importance is given to that difference by the singer of the song. The Creole singer in this song falls in love with "a nice Spanish gal." He describes their first conversation as follows:

Den I aks her in English,

"What is your name, young lady?"

An she answered in Spanish to me,

"¿Quién sabe? ¿Quién sabe, señor?"

Later, the singer begins to address the girl in Spanish instead of English. In this song, as in the Anansi tale, there is an acute awareness of ethnic difference, but there is no evidence of any comment on it, such as an undervaluing of one ethnic group relative to another.

Yet another instance of folklore that exhibits a clear awareness of ethnic difference is a Belizean version of "Brown-skin Girl." The following is the short song collected in Belize:

Brown skin gyal, stay home an mind di baby.

Brown skin gyal, stay home an mind di baby.

I am gwine away in a sailing boat

An if ah don't come back throw weh di damn baby.

Di baby fava wahn Chinaman.

Di baby fava wahn coolie man.

Woman, no badda mi

Because di pickney da no fi me (Beck 1978: 39).

In this song, as in the two selections above, the awareness of ethnic and/or racial difference is central, but there is no indication of the attachment of any negative sentiment to that awareness.

The second group of selections of folklore that I will discuss are those that evidence not only an awareness of ethnic difference but also the existence in the informant's mind of a racial or ethnic hierarchy. In these selections we find the undervaluation of certain races or ethnic groups relative to others. 
The first two of the described selections portray dark skin and hair as negative attributes. One is a folktale in which figure an ugly sister and a pretty one, apparently both darkskinned (Hagerty 1978: 121). After a witch makes the ugly one pretty by causing her hair and skin to turn golden, the originally pretty sister insists on being likewise transformed by the witch. However, the witch causes the pretty sister's hair to turn black: "Su pelo quedó negro, negro, negro. Quedó más fea." ("Her hair turned black, black, black. She became ugly.") Thus, even a pretty dark-skinned girl can become ugly if she becomes too dark and, conversely, becoming lighter automatically causes an ugly dark-skinned girl to become pretty.

Another tale that reveals the same attitude toward darker people involves a king who attempts to identify his true son (Hagerty 1978: 137). He is duped into believing that a charcoal vendor, blackened with his own merchandise, is his son and at first sight of him, he decides that this son is bad: "'Este hijo es regular de malo', dice. Lo vio que estaba feo. Dice, 'Este es regular de malo', dice." ("'This son is really bad', he says. He saw that he was ugly. He says, 'This one's really bad', he says.") The blackened would-be son is thus instantly judged to be ugly and bad merely because of his skin color.

Another instance of overvaluation of lightness and undervaluation of darkness is to be found in a folksong collected by Ervin Beck from Cleopatra White. Beck notes that

Cleopatra claims that this popular song is based on an incident that occurred in Roaring Creek when she worked there as a public health nurse. A young man was abandoned by his sweetheart and is now reduced to doing his own, bad cooking. But he gloats a little, since he has taken up with a lighter-skinned woman (1978: 36).

In the song the spurned lover, after complaining about his poor cooking, comforts himself by reminding himself, or bragging to his lost love, of the advantages of being without her:

I can read an write

An I can smoke me pipe.

An I can kiss a yella gal

At ten o'clock at night.

The worst taunt he can hurl at the woman who has spurned him is to let her know he has found someone better than her, that is, someone lighter.

In the many pages I studied in my research, I found only three ethnic jokes. Since the ethnic joke, by its very nature, betrays racial and ethnic prejudice, the paucity of such jokes in Belize lends support to claims of racial harmony there. And two of these jokes are insulting only to a small indigenous group called the Waika; those who would be offended by the jokes are few and not likely to hear them anyway. The first of these two jokes concerns a witless Waika Indian who buys a pair of shoes that are too large for him because in doing so, he says, "Me get more leather for me money" (Beck 1979: 326). The second joke tells of a non-Waika Belizean named Eddie who used to trick the Waika Indians into believing that he was a woman by putting on perfume and women's clothes (Beck 1979: 327-8). In this way, he managed to get himself wined and dined by the Waika men when they came into town each year for Christmas holidays. In the evening, after thoroughly enjoying himself and before the Waika has a chance, as the narrator says, "to enjoy the other side of his services", Eddie would excuse himself, change into his usual men's clothes and stroll by the waiting Waika 
without being recognized. The narrator is greatly amused by the image he conjures up of the deceived Waika: "You'd say anything to him, he'd say, 'Gyal, da bad gyal. E gi mi stay home [=She duped me]." The narrator's contempt for the Waika Indians is obvious in both of these jokes.

The third ethnic joke turns on the foolishness of a "Spanish man" ("el hombre español"), as he is called by the narrator, who lands in jail because neither he nor his two friends speak English (Hagerty 1978: 123). A man is murdered and when police come to investigate, the Hispanic man incriminates himself by using the only English words he knows - "I mi kill um." Things are made worse by the interference of his two friends who answer the policemen's questions using the only English phrases they know. As in the two Waika jokes, the narrator shows a great deal of contempt for the members of a specific ethnic group, but in this case the group in question is much more numerous in Belize than the Waika Indians. Thus, ethnic jokes such as the one involving the Hispanic man would be much more indicative than the Waika jokes of ethnic disharmony in Belize, but their scarcity is yet another testimony to Belize's racial harmony.

The last selection that I will discuss here is a folksong that I recorded in 1978. I place it in a third category in this study because it goes beyond the mere expression of the awareness of racial differences. In this unusual song, a girl points out the inequities in the lifestyles of Belizean white, brown and black girls, as she calls them (Beck 1978: 381).

All night long, Daddy, all night long.

(unintelligible) for my honeymoon. (chorus)

We di white girl eat ham and egg.

We di brown girl eat di same.

But we di poor black girl, we have to eat corn cakes, but we eating all di same.

\section{CHORUS}

We di white girl sleep on Simmons bed. We di brown girl sleep on di same. But we di poor black girl, we have to sleep on an old crocus bag, but we sleeping all di same.

\section{CHORUS}

We di white girl wear silk and satin dress. We di brown girl wear di same.

But we di poor black girl, we have to wear crocus bag, but we wearing all di same.

\section{CHORUS}

We di white girl wear patent shoes. We di brown girl wear di same. But we di poor black girl, we have to wear a pair of moccassin, but we wearing all di same. 


\section{CHORUS}

We di white girl drive in a Chevrolet car.
We di brown girl drive in di same.
But we di poor black girl,
we have to ride a poor old black jackass,
but we riding all di same.

\section{CHORUS}

The singer of this song finds the lifestyles of white and Hispanic girls much superior to that of black girls. In each stanza she notes the differences and then, possibly on the verge of protest against them, decides to reconcile herself to the unjust differences and even to accept them. The listener is unable to discern whether the singer's anger is repressed or there is actually no anger at all. These two possibilities are equally amazing: that in this age of protest the singer should feel unable or unwilling to express her resentment or that, in view of the inequities she observes, she should feel no resentment at all. But if we take the song at face value, the latter does seem to be the case.

The issue of race and ethnicity in Belize is a complex one. The evidence that I gleaned from a study of a large body of Belizean folklore points to a society conscious of its heterogeneity and sometimes aware of race-based inequities, although never incensed by them. It points, in sum, to a highly diverse society as racially harmonious as Belizeans claim their society is.

\section{References cited}

Beck, Ervin. 1978. Creole Folklsongs from Belize. Unpublished ms.

1979. Creole Folktales from Belize. Unpublished ms. Two volumes, continuously paginated.

Hagerty, Timothy W. 1978. Belizean Folk Narrative. Unpublished ms.

Parham, Mary Gomez and Timothy W. Hagerty. 1988. "Crossing Cultures: Anansi in Belize." Southern Folklore. 46 (1): 41-52. 